\title{
Density Distribution of Fish in the Presence of Whales at the Admiralty Inlet Landfast Ice Edge
}

\author{
R. CRAWFORD ${ }^{1}$ and J. JORGENSON ${ }^{1}$
}

(Received 29 June 1989; accepted in revised form 12 December 1989)

\begin{abstract}
Hydroacoustic techniques were used to search for fish beneath landfast sea ice in Admiralty Inlet, Northwest Territories, Canada, when narwhal (Monodon monoceros) and beluga whales (Delphinapterus leucas) were congregating at the ice edge in the mouth of the inlet. Fish, presumably Arctic cod (Boreogadus saida), were distributed in the water column within four general layers or zones: near the ice undersurface, about $40 \mathrm{~m}$ deep, about $80-100 \mathrm{~m}$ deep, and about $150-200 \mathrm{~m}$ deep. The distribution of the first three layers roughly corresponded with the distribution of larger zooplankters, also estimated hydroacoustically. We recorded higher densities immediately below the ice than farther down in the water column. Maximum density in both regions occurred about $10 \mathrm{~km}$ from the ice edge. Fish density was low in the immediate vicinity of the ice edge. The distribution of fish underneath the landfast ice of Admiralty Inlet is postulated to have been influenced by the distribution of zooplankton, their principle food source, rather than by the presence of whales.
\end{abstract}

Key words: Arctic cod, Boreogadus saida, landfast ice edge, hydroacoustics, narwhal, beluga

RÉSUMÉ. Des techniques hydroacoustiques ont été utilisées pour rechercher la présence de poissons sous la banquise côtière de la baie de l'Amirauté (Admiralty Inlet) dans les Territoires du Nord-Ouest (Canada), au moment où des narvals (Monodon monoceros) et des bégluas (Delphinapterus leucas) se rassemblaient à la lisière des glaces à l'entrée de la baie. Des poissons, vraisemblablement des morues arctiques (Boreogadus saïda), étaient distribués dans la colonne d'eau en quatre grandes couches ou zones: près du plafond glaciel et à des profondeurs respective d'environ 40,80-100 et 150-200 m. La distribution des trois premières couches correspond grossierement à la distribution des organismes zooplanctoniques de grande taille; leur répartition a elle aussi été évaluée par des méthodes hydroacoustiques. Les densités enregistrées étaient plus élevées immédiatement sous las glace que dans la colonne d'eau. Dans ces deux endroits, la densité maximale a été enregistrée à environ $10 \mathrm{~km}$ de la lisière des glaces. La densité des poissons était faible dans le voisinage immédiat de la lisière des glaces. On a posé l'hypothèse que la distribution des poissons sous la banquise côtière de la baie de l'Amirauté avait été influencée par la distribution du zooplancton, qui constitue leur principal source d'alimentation, plutôt que par la présence de baleines.

Mots clés: morue arctique, Boreogadus saïda, banquise côtière, lisière des glaces, hydroacoustique, narval, béluga

\section{INTRODUCTION}

The Arctic cod (Boreogadus saida Lepechin 1773), sometimes called polar cod, is an extremely important component of the arctic food web, yet relatively little is known about its numbers or habits (Bradstreet et al., 1986). It has a circumpolar distribution at high northern latitudes and is known in Canadian waters from the Gulf of St. Lawrence (Scott and Scott, 1988) to the Beaufort Sea and High Arctic Archipelago (Bradstreet et al., 1986). In the limited diversity of the arctic marine food web, it represents the major link between the secondary producers (zooplankton) and the top carnivores (marine mammals and seabirds) (Andriashev, 1964; Bradstreet et al., 1986; Finley and Gibb, 1982; Frost and Lowry, 1984; Mansfield et al., 1975; Sergeant, 1973). It is also food for other fishes, such as Arctic char (Moore and Moore, 1974). As Bradstreet et al. (1986) point out, the lack of available alternate foods for the top arctic carnivores underscores the importance of Arctic cod as a food source.

Arctic cod are extremely catholic in their food habits; availability appears to play an important role in their selection of food items. They have an apparent preference for copepods and amphipods (Bradstreet et al., 1986), although their diet is known to vary both geographically and seasonally (Lowry and Frost, 1981). Lonne and Gulliksen (1989) concluded that the diet of Arctic cod associated with ice reflects the composition of the crustacean community on the ice undersurface and in the adjacent water masses.

Much of the limited information describing the distribution of this fish in the Canadian Arctic has been generated by ancillary observations executed during studies of other phenomena. For example, inferences about its preponderance in the under-ice community have been made during observations of sea birds feeding in the wakes of passing ice breakers (Andriashev, 1970). The few studies specifically directed at Arctic cod often include observations made under ice using SCUBA and have led to the assumption that these fish rarely school there, although divers have observed scattered individuals near fractures and other ice features (Bain and Sekerak, 1978; Lonne and Gulliksen, 1989). The assumed close relationship between Arctic cod and ice was exemplified by Dunbar (1981), who suggested that the placement of the Arctic cod's mouth may represent adaptation to under-ice feeding.

Although the Arctic cod literature is not extensive, and much of it is of the "grey" variety, it is replete with observations of the role Arctic cod plays in the landfast ice-edge ecosystem (Bain et al., 1977; Bradstreet, 1977, 1980, 1982; Bradstreet et al., 1986; Dunbar, 1981; Sekerak and Richardson, 1978). The ice edge is postulated to be a site of local oceanic upwelling (Buckley et al., 1979), and such areas are known to be sites of high fish production (Dunbar, 1981). It has been suggested that congregations of birds and marine mammals occur there because of enhanced feeding opportunities (Bradstreet and Cross, 1982; Dunbar, 1981). Presumably, augmented primary and low-level secondary productivity at the ice edge attracts Arctic cod, which represent an abundance of food for the higher predators. Although few direct observations of large aggregations of Arctic cod at this feature have been made, its abundance has been inferred from its preponderance in the stomach contents of seabirds and marine mammals studied there (Finley and Gibb, 1982).

Estimates of the density of Arctic cod at features such as the landfast ice edge are important in the understanding of prey densities required to attract and/or energetically support various predators. Knowledge of the role that Arctic cod plays in the dynamics of these ecosystems is an important con-

\footnotetext{
${ }^{1}$ Science Branch, Department of Fisheries and Oceans Canada, Freshwater Institute, 501 University Crescent, Winnipeg, Manitoba, Canada R3T 2N6
} 
sideration in the evaluation of potential perturbations caused by the passage of ice breakers through these areas. This evaluation has recently become politically pertinent because the landfast ice edge can be an important Inuit hunting site (e.g., near locations such as Pond Inlet and Admiralty Inlet). Hydrocarbon and mineral exploitation in the Arctic is anticipated to increase icebreaker activity and an understanding of the potential for adverse impacts is required (Mansfield, 1983). These considerations led to the examination of Arctic cod distribution in Admiralty Inlet reported here.

Admiralty Inlet, bordering on Lancaster Sound at the northwest side of Baffin Island, Northwest Territories, is a common gathering area of narwhals (Monodon monoceros) and harp seals (Pagophilus groenlandicus) (Bradstreet et al., 1986). Beluga whales (Delphinapterus leucas) also occur in the inlet as they make their way toward areas farther west. Although harp seals do not usually appear in the inlet until late summer, narwhals and beluga often arrive by early June and follow the ice edge into the inlet during ice breakup. The ice edge in Admiralty Inlet is considered by the local Inuit to be a traditional whale hunting site. In 1986, the Department of Fisheries and Oceans Canada (DFO) began studying the behaviour of narwhals and belugas in the inlet in conjunction with the passage of the MV Arctic, an icebreaking ore carrier that services the Nanisivik mine there. During this work, and as an extension of a DFO investigation of marine fish in the Canadian Arctic that began in 1985, hydroacoustic techniques were used in the inlet to examine the density of pelagic fish beneath the landfast ice during a time when whales were at the ice edge.

\section{MATERIALS AND METHODS}

\section{Procedures}

In June 1986 and 1988, we used hydroacoustic equipment (BioSonics, Inc., Seattle, WA) to study fish distribution beneath the fast ice in Admiralty Inlet (Fig. 1). The system was a dual-beam type. With this equipment, differences between echoes received on the separate narrow and wide beams can be related to an estimate of fish size (Ehrenberg, 1974); other information received on the narrow beam can be related to fish density and abundance. The system operated at $200 \mathrm{kHz}$ and had acoustic beam widths of $6^{\circ}$ and $15^{\circ}$. It also included a high-resolution graphic chart recorder, digital data-recording equipment, and various support devices (oscilloscope, etc.) (Fig. 2). The equipment was secured to a komatik, a type of Inuit sledge, and towed by snow machine to various sampling sites in the inlet.

At each site, a $25 \mathrm{~cm}$ hole was augered through the ice, typically $1.7 \mathrm{~m}$ thick, and the transducer was lowered to a position about $10-20 \mathrm{~cm}$ below the ice undersurface. The transducer was mounted on a tiltable device (Fig. 3) that allowed varying the vertical orientation of the search pattern. It was aimed either vertically toward the seabed or horizontally, parallel to the ice undersurface. The vertical search extended downward to the seabed or to $250 \mathrm{~m}$ (one of two selectable limits of the acoustic receiver's time varied gain [TVG] circuitry), whichever was less.

Horizontal searches were usually limited to $125 \mathrm{~m}$ (the other TVG range limit). Interference from undersurface features occasionally reduced the maximum range at which individual targets could be resolved in echograms to a figure less than

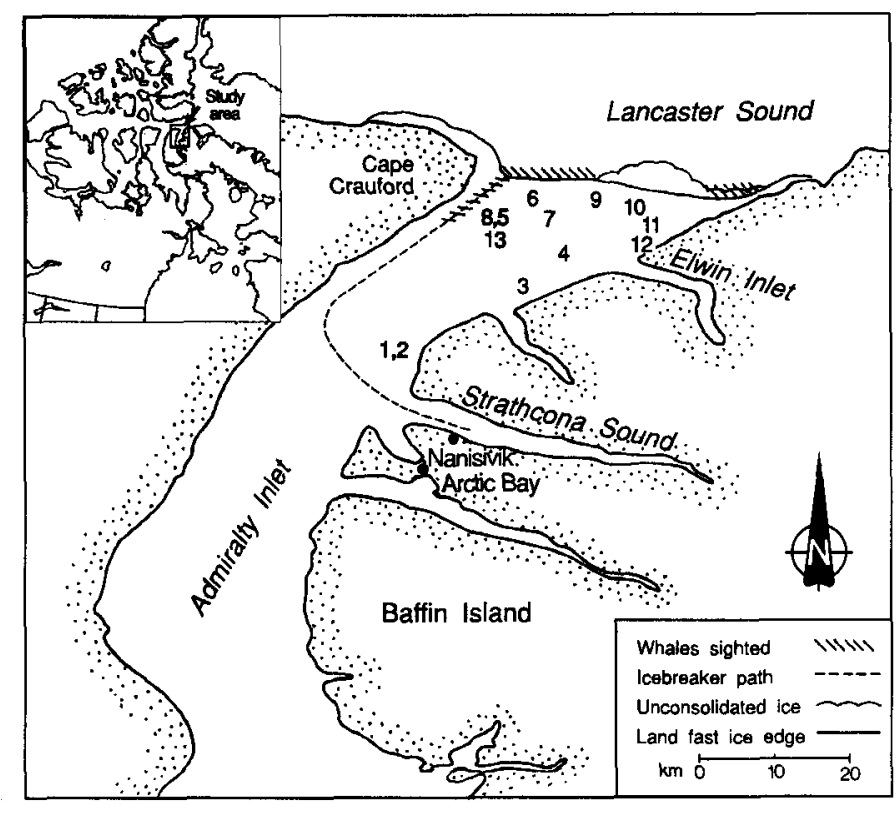

FIG. 1. Location of Admiralty Inlet in the eastern Canadian Arctic and the location of stations occupied during an 18-21 June 1988 survey for fish beneath landfast sea ice there. Ice cover in the depicted area of Lancaster Sound was $>1 / 10$ during the study period.

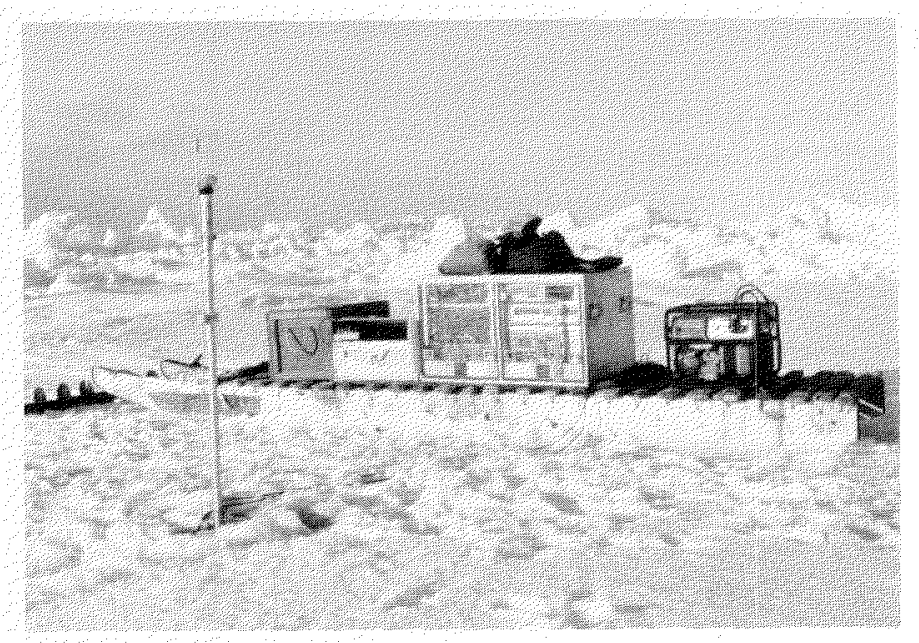

FIG. 2. Hydroacoustic equipment used for sampling fish density distribution beneath landfast sea ice in Admiralty Inlet. The system's transducer (Fig. 3) is attached to the handle or pole that extends vertically from a sampling hole augered through the ice.

this. Sometimes interference was sufficient so as to preclude successful horizontal observation altogether.

Video recordings have revealed that schools of small Arctic cod occasionally maintain their position against a current near a smooth ice undersurface (D. Pike, DFO Iqaluit, N.W.T., unpubl. data). Because we had detected this species under ice off nearby Cornwallis and Devon islands during previous studies, we directed the transducer orthogonally to the current so that schooling fish would be oriented sideways to our beam. We estimated the direction of current flow by tilting the transducer slightly and observing the trace of zooplankters drifting through the acoustic beam. (The angle of the beam is fixed to slightly off-vertical. The beam is then rotated by turning the transducer until the zooplankton traces on the echogram are maximally slanted; the beam is now orthogonal 


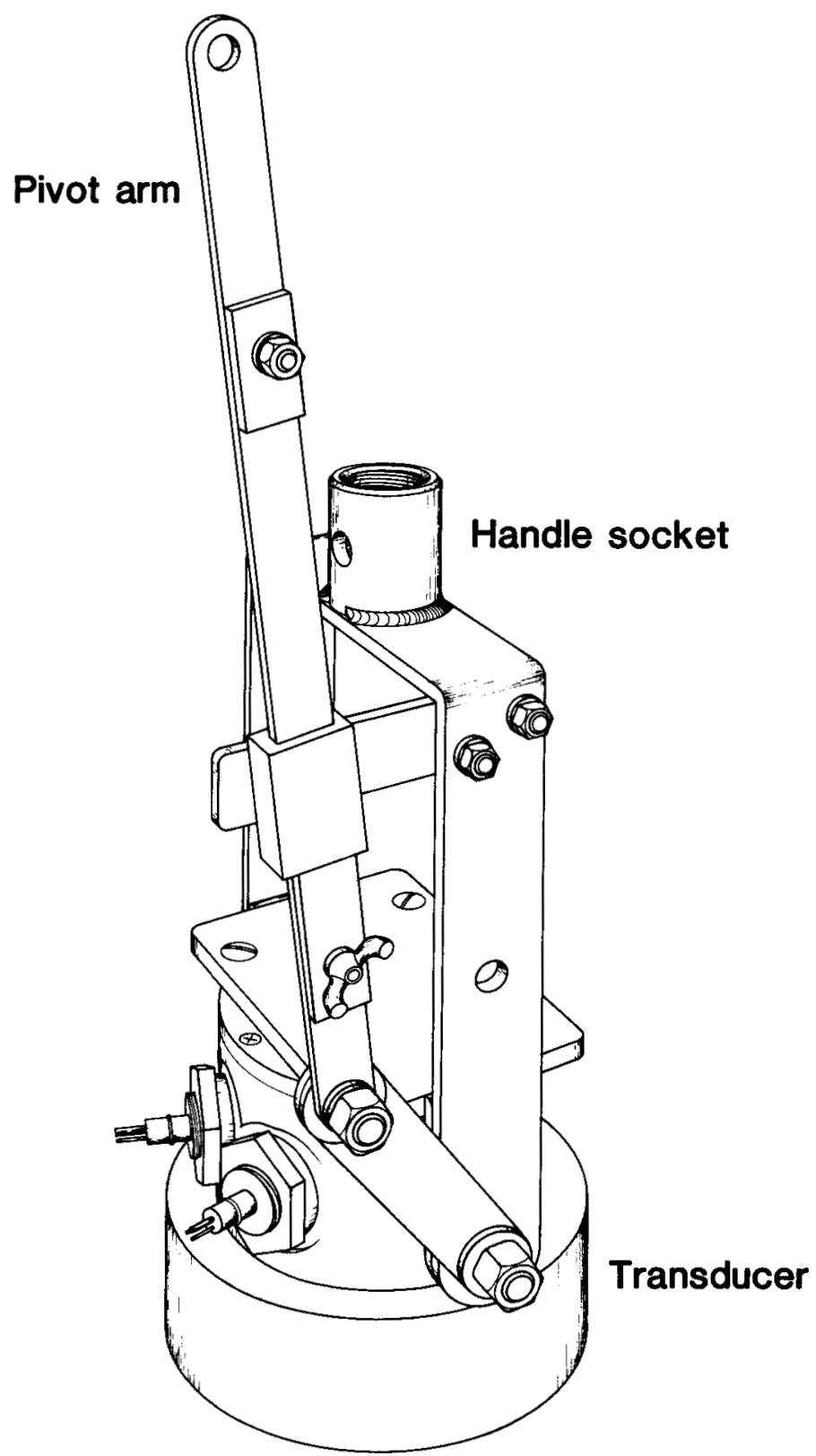

FIG. 3. Pivoting mount for operating a transducer beneath fast ice. Pushing down on the pivot arm changes the search angle from vertical (indicated) toward the horizontal.

to current flow. The direction of echogram slant is related to current direction.)

At one station during the 1986 survey, we mounted the transducer on a drogue that was lowered beneath the ice on a long cable. The drogue was designed to maintain the orientation of the transducer's beam vertically downward as it is lowered in currents in order to extend the useful working range of the hydroacoustic system beyond the normal limits imposed by the TVG circuitry.

Although we attempted to sample in a grid pattern, in practice, station location was dictated by ice surface conditions. We avoided areas that appeared unsafe and also places where we expected ice thickness to exceed the length of our auger (ice older than one year, pressure ridges, etc.). Our sampling was also influenced by the activities of indigenous hunters. Our operations required the use of a motor-driven generator, which was a source of potential disturbance to hunting activities. We did not sample when hunting was in progress in the vicinity. A typical station consisted of approximately 60 min of vertical observations and $20 \mathrm{~min}$ of horizontal observations. We stored digitized hydroacoustic data on video cassette for later analysis in the laboratory.

During 1986, we monitored dual-beam system performance by recording echoes from a ping pong ball suspended beneath the transducer. In 1988, the dual-beam portion of the system was inoperable, so only single-beam recordings were made. System performance calibrations for those data were performed in May 1988 by BioSonics Inc. (Seattle, WA). During both surveys, a correction to account for spherical spreading losses in the acoustic beam ( 40 times the common logarithm of the target's range) was applied to data to allow target strength determination and/or echo counting.

In the laboratory, we replayed data recordings into the chart recorder to optimize the quality of the echograms generated by the data. Then we counted the number of fish-like targets that we interpreted to be those that had either target strength values similar to those of known fish targets we had previously studied elsewhere in the Arctic (R. Crawford, unpubl. data) or else were those that generated echograms typical of fish (e.g., obvious swimming movements).

The relative density and distribution of zooplankters was monitored by occasionally increasing the gain of the hydroacoustic receiver to levels higher than that required for fish detection. Fish target strengths were determined with a BioSonics, Inc., dual-beam processor.

The counts of fish were assigned to depth ranges and were then adjusted with a weighting factor developed for use with fixed-location hydroacoustic studies (BioSonics, Inc., Seattle, WA). This correction accounts for the conical shape of the transducer's sampling beam. Because the volume within the beam increases in direct proportion to the distance from the transducer, each count is corrected with a geometric weighting factor that decreases with range. A fish detected closer to the transducer is weighted more than a fish detected farther away, in effect rendering a cylindrical sampling volume. We did not sample the upper two metres, nearest the transducer face, and they were omitted.

Theoretically, the conical shape of the acoustic beam and its dimensions dictate that the maximum distance that targets could be detected from the ice undersurface would be about $6 \mathrm{~m}$ at a range of $125 \mathrm{~m}$, if we assume that one-half of the beam is flattened by the ice. But previous testing during horizontal searches revealed that acoustic energy is reflected off the ice into the water column (R. Crawford, unpubl. data). With our equipment, this reflection is sufficient to obtain an echo from the seabed at depths up to $100 \mathrm{~m}$. Because the effects of these reflections on the size of the horizontal acoustic search area were unknown, we assumed the same beam shape for both search directions. Our goal was to derive a relative comparison between the utilization of the pelagic zone beneath the ice with the use of the habitat near the ice undersurface, sometimes inferred to be preferred habitat. Overestimating the size of the horizontal search area would tend to reduce our estimates of fish density near the ice. We preferred to err on the conservative side and acknowledged that actual densities may have been higher.

Fish density was expressed as counts of fish per square metre, according to the area of the base of the sampling beam. 
Counts were determined for a standard 10 min sampling interval to allow comparison between stations and were multiplied by 100 to reduce the number of decimal places. Fish density was similarly determined for each cubic metre within the sampling volume. Fish distribution within the study area was interpolated (Surfer computer program, Golden Software, Inc., Golden, $\mathrm{CO}$ ) from station data so that the distribution of fish under the ice and in the water column in relation to the location of the whales and the ice edge could be evaluated. The dimensions of the interpolated areas for the horizontal and vertical surveys were determined with a digitizing pad so that average counts could be expanded across the study area.

\section{Field Surveys}

In late May 1986, while we were studying marine fish distribution in nearby Barrow Strait, we were informed that open water (ice cover $<1 / 10$ ) extended from the Admiralty Inlet ice edge well into Lancaster Sound and that narwhals were near the ice edge (S. Cosens, pers. comm. 1986). During the time required to arrange for support aircraft to relocate our field camp to the ice edge, which extended across the mouth of the inlet, ice conditions changed and very close pack ice (ice cover $9 / 10$ to $10 / 10$ ) extended several kilometres into the sound during our study period. The pack ice precluded the passage of whales to the ice edge, and none was observed there until about a week after we left the area. Also, difficult ice travel conditions that year limited our search for fish to a relatively small area about $8 \mathrm{~km}$ long and about $1 \mathrm{~km}$ wide along the western portion of the ice edge.

During three days of observations we recorded a total of $267.2 \mathrm{~min}$ of dual-beam hydroacoustic data at five locations. To enhance the possibility of detecting deeper targets at one station (water depth $=193.9 \mathrm{~m}$ ), the transducer was lowered on the drogue to $60 \mathrm{~m}$ for $43.75 \mathrm{~min}$.

In June 1988, both narwhal and beluga were at the ice edge and conditions for travel were more favourable. We delayed the timing of our survey until late June to reduce the possibility of a change in open-water conditions such as had occurred previously. Rather than airlift our gear to the study area as we had done before, we towed the komatik-mounted equipment to the ice edge from the hamlet of Arctic Bay. This travel provided the opportunity for observations at various locations along the route (Fig. 1). Open water extended to within several hundred metres of the ice edge during our study period and only a narrow region of pack ice (ice cover 4/10 to 6/10) separated the ice edge from open water. Narwhal were frequently observed on the western side of the inlet in this pack ice and also in the lead in the inlet created by the earlier passage of the MV Arctic (Fig. 1). Beluga were at the inlet's eastern side, but they did not penetrate the pack ice, as did the narwhal.

On 18-21 June 1988, $757.6 \mathrm{~min}$ of data recording at 13 locations yielded a total of 218 targets we classified as fish. Unfortunately, we were unable to collect any target strength information on these targets.

\section{RESULTS}

During our 1986 observations, we did not detect fish at any station, either near the bottom surface of the ice or in the water column. The relative numbers of zooplankter traces on the echograms were also low in comparison to observations we made in Barrow Strait near Cornwallis Island several days earlier.

In contrast, during the 1988 survey we recorded fish-like targets throughout the water column. Fish distribution fell into roughly four layers: near the ice undersurface (Fig. 4a), about $40 \mathrm{~m}$ deep, about 80-100 $\mathrm{m}$ deep, and about 150-200 $\mathrm{m}$ deep (Fig. 5). The first three layers approximated the distribution of concentrations of zooplankters that we could observe in the water column (Fig. 4b).

The fish under the ice were concentrated in an area about $10 \mathrm{~km}$ from the ice edge (Figs. 6,7) and fish densities were highest near the ice undersurface (Table 1). Mean and standard deviation values for the stations with horizontally oriented ice undersurface observations are:

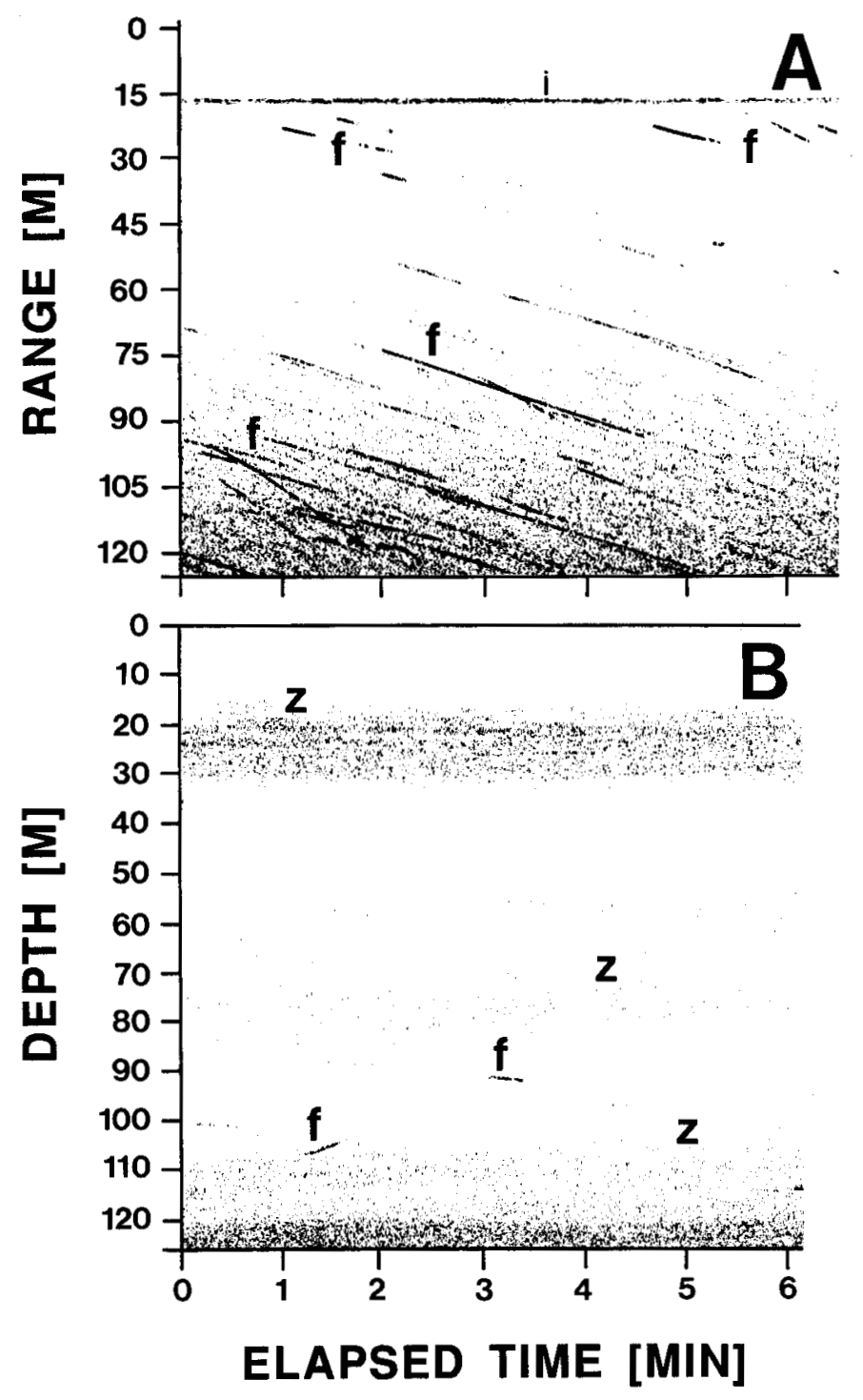

FIG. 4. A) Acoustic echogram of fish near the undersurface of landfast ice in Admiralty Inlet at station 3 (see Fig. 1). The transducer was $10 \mathrm{~cm}$ below the ice and aimed parallel to the undersurface. Marks such as those labelled f depict fish moving slowly near the ice. A reflection (i) from the ice undersurface at $16 \mathrm{~m}$ is also indicated. Range scale indicates horizontal distance from the transducer. Shaded area is primarily caused by acoustic "noise" but also likely contains echoes from zooplankters.

B) Acoustic echogram of zooplankters and fish in the water column beneath landfast ice in Admiralty Inlet at station 3 (see Fig. 1). Three layers of zooplankton (z) and several fish targets (f) are indicated. 
$2.78 \mathrm{E}+00(4.40 \mathrm{E}-02)$ targets $\cdot 100 \mathrm{~m}^{-2} \cdot 10 \mathrm{~min}(\mathrm{n}=10)$ and

$2.31 \mathrm{E}-02(3.56 \mathrm{E}-02)$ targets $\cdot 100 \mathrm{~m}^{-3} \cdot 10 \mathrm{~min}(\mathrm{n}=10)$. Similar statistics for the water column observations (vertical search) are:

$6.51 \mathrm{E}-01(6.03 \mathrm{E}-03)$ targets $\cdot 100 \mathrm{~m}^{-2} \cdot 10 \mathrm{~min}(\mathrm{n}=13)$ and

$2.94 \mathrm{E}-03(2.82 \mathrm{E}-05)$ targets $\cdot 100 \mathrm{~m}^{-3} \cdot 10 \mathrm{~min}(\mathrm{n}=13)$.

We did not statistically compare the differences between the mean values from the two search aspects, horizontal and vertical, because of the previously discussed uncertainties

\section{STATION NUMBER}

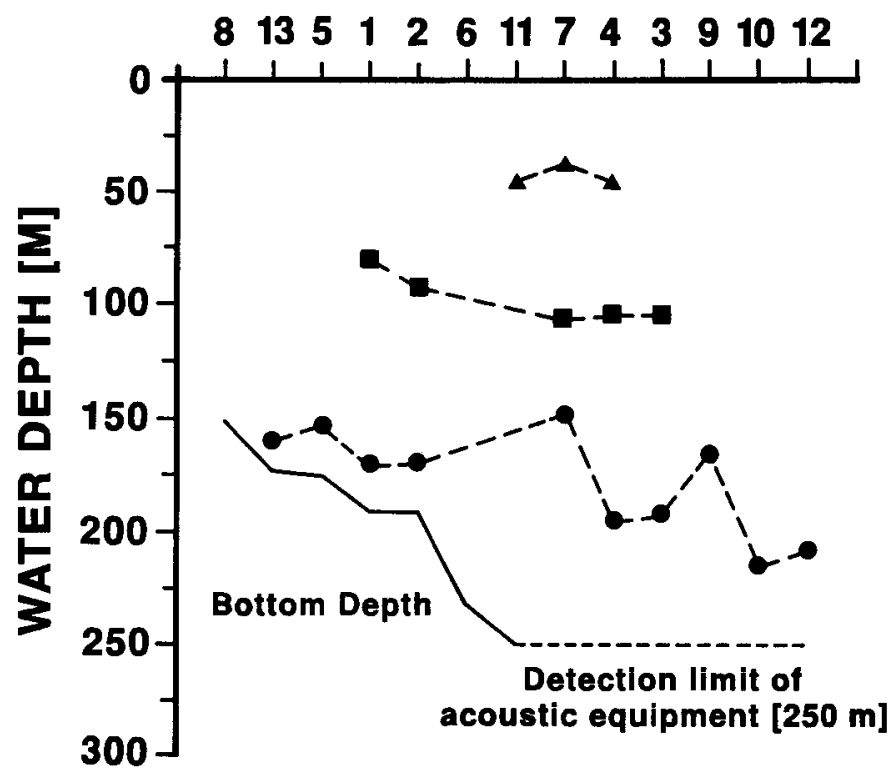

FIG. 5. Depth distribution of fish detected acoustically beneath landfast sea ice in Admiralty Inlet. Station order has been arranged according to target distribution to simplify interpretation.

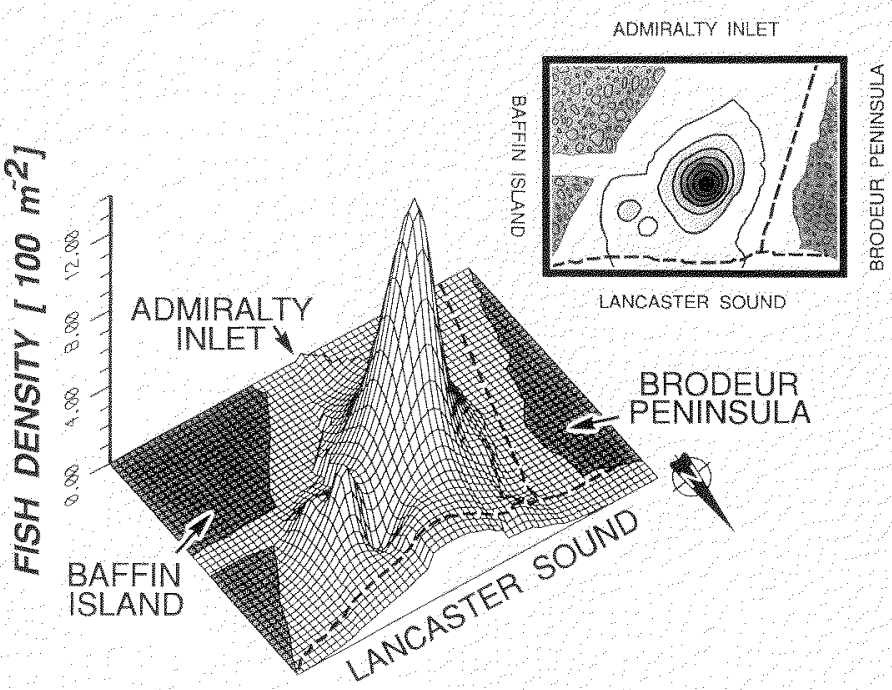

FIG. 6. The density distribution of fish near the ice undersurface in Admiralty Inlet, 18-21 June 1988, as determined with a hydroacoustic transducer aimed parallel to the ice. Density is expressed as the $10 \mathrm{~min}$ average number of fish detected per $100 \mathrm{~m}^{2}$. Refer to Figure 1 for station location and orientation of features such as the ice edge and an ice breaker's track in the ice. The contour plot (inset) depicts this distribution in relation to the ice edge and the geographic features at the mouth of Admiralty Inlet.

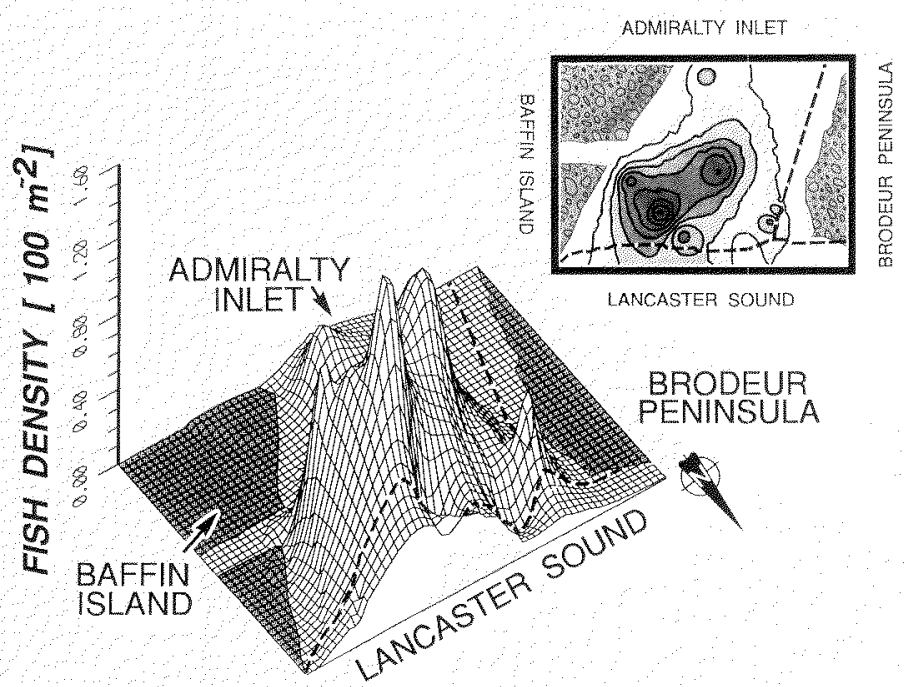

FIG. 7. The density distribution of fish within the water column (to $250 \mathrm{~m}$ ) beneath landfast sea ice in Admiralty Inlet, 18-21 June 1988, as determined with a hydroacoustic transducer aimed vertically. Details same as for Figure 6.

about the true sampling volume for the horizontal data. But we noted that there was a significant difference between the variances within the two data sets (variance ratio test, $P<0.001$ ), and the variance of the horizontal data set was higher.

We also did not use fishing gear to groundtruth our acoustic sampling, but we did capture one small Arctic cod that was swimming in the augered hole at station 1 . This fish was a male, $136 \mathrm{~mm}$ in total length, and weighed $17.3 \mathrm{~g}$. The same hole was used for station 2, eight hours later, but no more fish appeared.

Because of the low numbers of slow-moving fish we detected and the relatively brief period we used as a sampling interval, our data approximate an instantaneous snapshot of fish distribution beneath the ice during the study period. Accordingly, we can derive a preliminary estimate of fish abundance in the study area from these data. The interpolated surface areas of those portions of the study area found to contain fish (represented by fish density levels $>1.100 \mathrm{~m}^{-2}$ for the ice undersurface survey [Fig. 6] and $>0.1 \cdot 100 \mathrm{~m}^{-2}$ for the water column survey [Fig. 7]) were $600 \mathrm{~km}^{2}$ and 800 $\mathrm{km}^{2}$ respectively. Given the previously noted average values of fish density for each survey, and allowing that uncertainties about them would influence our results, we conservatively estimated the approximate fish abundance near the ice to be about 16.5 million, while about 5 million were in the water column (to a maximum depth of $250 \mathrm{~m}$ ). A sample of 285 Arctic cod we collected from Lancaster Sound off nearby Cornwallis and Devon islands in 1985 and 1986 had a pooled average live weight of $28.9 \mathrm{~g}$ (range 0.9-108.0 g). Applying this average weight to the number of Arctic cod that we estimated were in the study area yielded an approximate fish biomass of 0.79 metric tons $(\mathrm{t}) \cdot \mathrm{km}^{-2}$ or $630 \mathrm{t}$ in the study area.

\section{DISCUSSION}

We assume the fish we acoustically detected beneath the ice in Admiralty Inlet were Arctic cod. The apparent echo strength and echograms produced by the targets we classified as fish in the inlet were consistent with recordings of Arctic cod we made previously beneath the ice off nearby Cornwallis 
TABLE 1. Estimates of fish density beneath landfast sea ice in Admiralty Inlet, 18-21 June 1988, derived from the number of targets detected acoustically either in the water column (Vert $=$ vertical sampling angle) near the under-ice surface (Hor $=$ horizontal sampling angle)

\begin{tabular}{|c|c|c|c|c|c|c|}
\hline Station & Water depth (m) & Sampling depth or range $(\mathrm{m})^{\mathrm{a}}$ & Sampling angle & Sampling duration (min) & Fish $\left(100 \cdot \mathrm{m}^{-2} \cdot 10 \mathrm{~min}\right)$ & Fish $\left(100 \cdot \mathrm{m}^{-3} \cdot 10 \mathrm{~min}\right)$ \\
\hline 1 & 191 & 191 & Vert & 63.2 & 1.85 & $9.68 \mathrm{E}-03$ \\
\hline 2 & 191 & 191 & Vert & 46.8 & 0.625 & $3.28 \mathrm{E}-03$ \\
\hline 3 & 400 & $\begin{array}{l}250 \\
125\end{array}$ & $\begin{array}{l}\text { Vert } \\
\text { Hor }\end{array}$ & $\begin{array}{r}18.7 \\
9.3\end{array}$ & $\begin{array}{l}0.366 \\
0.0\end{array}$ & $\begin{array}{l}1.47 \mathrm{E}-03 \\
0.0\end{array}$ \\
\hline 4 & $400+$ & $\begin{array}{l}250 \\
125\end{array}$ & $\begin{array}{l}\text { Vert } \\
\text { Hor }\end{array}$ & $\begin{array}{l}83.7 \\
21.0\end{array}$ & $\begin{array}{l}1.11 \\
14.5\end{array}$ & $\begin{array}{l}4.46 \mathrm{E}-03 \\
1.17 \mathrm{E}-01\end{array}$ \\
\hline 5 & 175 & $\begin{array}{l}175 \\
125\end{array}$ & $\begin{array}{l}\text { Vert } \\
\text { Hor }\end{array}$ & $\begin{array}{l}46.6 \\
20.2\end{array}$ & $\begin{array}{l}0.558 \\
0.0\end{array}$ & $\begin{array}{l}3.20 \mathrm{E}-03 \\
0.0\end{array}$ \\
\hline 6 & 232 & $\begin{array}{l}232 \\
125\end{array}$ & $\begin{array}{l}\text { Vert } \\
\text { Hor }\end{array}$ & $\begin{array}{l}47.7 \\
15.5\end{array}$ & $\begin{array}{l}0.0 \\
1.44\end{array}$ & $\begin{array}{l}0.0 \\
1.16 \mathrm{E}-02\end{array}$ \\
\hline 7 & 300 & $\begin{array}{l}250 \\
125\end{array}$ & $\begin{array}{l}\text { Vert } \\
\text { Hor }\end{array}$ & $\begin{array}{l}69.0 \\
11.3\end{array}$ & $\begin{array}{l}0.290 \\
1.97\end{array}$ & $\begin{array}{l}1.16 \mathrm{E}-03 \\
1.58 \mathrm{E}-02\end{array}$ \\
\hline 8 & 151 & 151 & Vert & 22.7 & 0.0 & 0.0 \\
\hline 9 & 300 & $\begin{array}{r}250 \\
90\end{array}$ & $\begin{array}{l}\text { Vert } \\
\text { Hor }\end{array}$ & $\begin{array}{l}68.0 \\
20.1\end{array}$ & $\begin{array}{l}0.041 \\
2.86\end{array}$ & $\begin{array}{l}1.64 \mathrm{E}-04 \\
3.19 \mathrm{E}-02\end{array}$ \\
\hline 10 & 450 & $\begin{array}{l}250 \\
125\end{array}$ & $\begin{array}{l}\text { Vert } \\
\text { Hor }\end{array}$ & $\begin{array}{l}43.8 \\
18.5\end{array}$ & $\begin{array}{l}0.987 \\
2.41\end{array}$ & $\begin{array}{l}3.96 \mathrm{E}-03 \\
1.94 \mathrm{E}-02\end{array}$ \\
\hline 11 & 480 & $\begin{array}{l}250 \\
125\end{array}$ & $\begin{array}{l}\text { Vert } \\
\text { Hor }\end{array}$ & $\begin{array}{r}32.8 \\
8.0\end{array}$ & $\begin{array}{l}1.00 \\
4.65\end{array}$ & $\begin{array}{l}4.02 \mathrm{E}-03 \\
3.74 \mathrm{E}-02\end{array}$ \\
\hline 12 & 320 & $\begin{array}{l}250 \\
125\end{array}$ & $\begin{array}{l}\text { Vert } \\
\text { Hor }\end{array}$ & $\begin{array}{r}39.8 \\
7.3\end{array}$ & $\begin{array}{l}1.52 \\
0.0\end{array}$ & $\begin{array}{l}6.09 \mathrm{E}-03 \\
0.0\end{array}$ \\
\hline 13 & 173 & $\begin{array}{l}173 \\
250\end{array}$ & $\begin{array}{l}\text { Vert } \\
\text { Hor }\end{array}$ & $\begin{array}{r}35.1 \\
8.5\end{array}$ & $\begin{array}{l}0.120 \\
0.0\end{array}$ & $\begin{array}{l}6.98 \mathrm{E}-04 \\
0.0\end{array}$ \\
\hline
\end{tabular}

aSampling depth was limited by either the water depth or the setting of the hydroacoustic receiver's time varied gain circuitry (TVG).

and Devon islands. Hansen and Dunbar (1970) obtained similar echograms during studies done in the late 1960 s from Ice Island T-3 as it drifted northward in the Chukchi Sea. During three seasons of work, their fishing efforts to groundtruth these echograms produced nine specimens of polar cod (Arctogadus glacialis) and two Arctic cod. The authors assumed most of the targets they observed were polar cod. During four seasons of work in Lancaster Sound, using various types of fishing nets, we have not encountered a single specimen of polar cod. Nor was there any evidence of this species in stomach samples taken from seabirds feeding in Lancaster Sound (Gaston and Nettleship, 1981). But we have collected many hundreds of Arctic cod, not including the one specimen we found during this study. The other pelagic species we have observed are the gelatinous snailfish (Liparis fabricii) and a single small, unidentified squid specimen. Neither of these species presents acoustic signals that would be expected to be routinely confused with that of an Arctic cod.

During our travel from the hamlet of Arctic Bay to our 1988 Admiralty Inlet study area described here, we visited an Inuit fishing camp in Adams Sound where a large catch ( $>100$ ) of Greenland cod (Gadus ogac) had been landed. This has been our only observation of this species in these waters and is an unusually northern observation of it in the Canadian Arctic Archipelago. That it occurs around northern Baffin Island and yet apparently does not commonly cross Lancaster Sound suggests that it is not a member of the local pelagic community. Although it was abundant at the fishing camp (water depth $<10 \mathrm{~m}$ ), we do not believe that it was among the fish we detected beneath the ice about $55 \mathrm{~km}$ away in the Admiralty Inlet study area.

We may conjecture that the low density of fish at the ice edge was a result of cropping by the whales. The Inuit hunters we camped with at the ice edge were not surprised that the fish were concentrated several kilometres away from the open water. According to them, the whales arrive at the ice edge each year because fish are abundant in the inlet each summer. They believe the whales pursue the fish but cannot reach them until the ice begins to break up, allowing them access to the inlet. The hunters, who were not aware of our research findings other than the fact that fish were not common at the ice edge, indicated on a map the area they believed to be the summer feeding grounds of the beluga and narwhals; this area approximated the same region of concentration depicted in Figures 6 and 7. The main concentration of fish several kilometres from the ice edge is assumed to be beyond the under-ice foraging distance of narwhal or beluga. However, the lower densities of pelagic fish that extended to the ice edge (Fig. 7) presumably represented food for diving whales.

It is also plausible that the absence of fish in the upper part of the water column near the ice edge in 1988 represented an avoidance response to the presence of predators, but we saw no evidence to suggest that. We hypothesize that the distribution of the fish was influenced by the location of the zooplankton, which is their food. We usually found fish at depths that approximated the layers of zooplankton that appeared in our echograms. This suggested that the fish were dispersed according to the distribution of their food supply. We postulate that the fish may simply have been following the concentration of their food source rather than responding to the whales.

Whether the whales use the inlet as a summertime feeding area is not clear. Researchers have found that narwhal in the waters of northern Baffin Island reduced their feeding 
activity during the open-water season, especially when compared with feeding that had occurred earlier at the ice edge (Mansfield et al., 1975; Finley and Gibb, 1982). This decrease was independent of Arctic cod abundance. These authors suggested that the summer season preference by narwhal for areas such as Admiralty Inlet is not related to feeding but rather to calving, which occurs during this time. We have observed beluga actively pursuing and feeding upon schools of Arctic cod off Cornwallis Island during August, so we know that these whales can be quite aggressive predators during the summer. But if narwhals do not enter Admiralty Inlet in search of food but rather to occupy a specific area for calving purposes, then the events that placed the fish in the narwhal summering area may have simply been coincidental.

We did not detect any fish at the western portion of the ice edge during either the 1986 or the 1988 survey, but during 1986 sampling was restricted to a small area. We do not know if fish were present at that time farther in the inlet, but that is a possibility. However, we have observed large annual fluctuations in the local abundance of Arctic cod elsewhere in the eastern Arctic (Crawford, unpubl. data), and similar fluctuations have been observed along the coast of the Beaufort Sea (Dunbar, 1981). These fluctuations cannot all be easily explained as sampling bias, as can our Admiralty Inlet data. Because of the concurrent lower incidence of zooplankton in the echograms obtained during the 1986 survey, our results suggest that there could have been fewer fish in the inlet too; these results remain inconclusive.

The overlap between the distributions of fish immediately beneath the ice (Fig. 6) and those deeper down (Fig. 7) is consistent with what we have learned about Arctic cod elsewhere. We have recorded them travelling large vertical distances within a few minutes (R. Crawford, unpubl. data). These pelagic habits of Arctic cod would be expected to take them throughout the water column in Admiralty Inlet. We interpret the representations presented in Figures 6 and 7 as two different portions of the same population that was in the inlet at that time. As noted above, there was more variation in density levels within the under-ice surface data set than in the data obtained from the water column. We attributed this difference to aggregated fish distribution near the ice undersurface. This patchiness is also consistent with previous observations we and others (Dunbar, 1981) have made elsewhere in the Arctic.

The extrapolation of the target counts per 10 min interval into fish density did not include the possibility of counting the same fish more than once during an observation period. During previous work, we have detected multiple passes of a single Arctic cod through the acoustic beam, but none of the echograms generated in Admiralty Inlet suggested this. It is possible that such an event did occur during this study, but we do not believe it happened sufficiently often to bias the interpretation of our results.

Although our Arctic cod biomass estimate of $0.79 \mathrm{t} \cdot \mathrm{km}^{-2}$ in the head of the inlet should be considered preliminary, it is within the realm of other results obtained elsewhere. A recent hydroacoustic investigation of seabird prey in the southeast Chukchi Sea determined that fish (mostly Arctic cod) biomass levels ranged from 0.70 to $35.5 \mathrm{t} \cdot \mathrm{km}^{-2}$ (J. Piatt, pers. comm. 1989). That our estimate is on the low end of this range appears appropriate. Representative echograms from the Chukchi work indicate higher densities of fish than we detected in Admiralty Inlet. Also, when compared with some of our echograms from Lancaster Sound, the fish densities we observed in the inlet were low. Seabirds are a good indicator of high fish densities, and few were feeding at the ice edge during our surveys. The few Northern Fulmars (Fulmarus glacialis) that were feeding there were apparently consuming zooplankton, not fish. When fish are abundant at an ice edge, bird feeding activity can be spectacular. Bradstreet (1977) estimated that just one species of seabird, the Thick-billed Murre (Uria Lomvia), consumed as many as 400 $t$ of Arctic cod along the ice edges near Cornwallis Island during a 33-day period in 1976 (using our average weight of $0.028 \mathrm{~kg}$ per fish). He also estimated that this seabird consumed about $0.5 \mathrm{t} \cdot \mathrm{d}^{-1}$ along each linear kilometre of ice edge in Wellington Channel. There is a murre colony at nearby Prince Leopold Island, as well as a Northern Fulmar colony at the mouth of Admiralty Inlet (Brown and Nettleship, 1981). Although neither species was actively feeding at the Admiralty Inlet ice edge during our 1988 survey, they are known to feed there (S. Cosens, pers. comm. 1989). Arctic cod is the most important prey species for these murres (Gaston and Nettleship, 1981), and although fulmars are opportunistic, they also feed heavily on Arctic cod when the fish are abundant (R. Crawford, pers. obs.). We may surmise that the seabirds in Lancaster Sound are consuming on the order of $100 \mathrm{t}$ of Arctic cod each week during the spring, and these fish probably represent only a fraction of the sound's fish biomass. There are also thousands of marine mammals there at that time: narwhal, beluga, ringed seal (Phoca hispida), harp seal (Phoca groenlandicus), bearded seal (Erignathus barbatus), and walrus (Odobenus rosmarus) (Kingsley et al., 1985). All of these species rely on the Arctic cod as prey (Bradstreet et al., 1986). Frost and Lowry (1984) have estimated that the birds and mammals of the Beaufort Sea consume almost $30000 \mathrm{t}$ of cod annually. Although differences in food preferences and availability make it inappropriate to directly compare Lancaster Sound data with estimates for the Beaufort Sea ecosystem, the relationship is relevant; all evidence suggests that the numbers representing Arctic cod biomass in the Canadian Arctic will be large.

Our density estimate of $0.003 \cdot 100 \mathrm{~m}^{-3}$ adult Arctic cod in the water column is appropriately lower than those reported for juveniles. Sekerak et al. (in Hunter, 1979) reported youngof-the-year densities of 3.76 and $6.77 .100 \mathrm{~m}^{-3}$ in two 1976 samples from Lancaster Sound. Hunter (1979) reported an average value of $0.181 \cdot 100 \mathrm{~m}^{-3}$ from samples taken from the Beaufort Sea, and an average juvenile Arctic cod density of $2.80 \cdot 100 \mathrm{~m}^{-3}$ was measured in samples from the eastern Chukchi Sea (Quast, 1974). This comparison of derived estimates of Arctic cod density should be considered with caution because we had adjusted our hydroacoustic equipment to respond primarily to larger targets; it would not be expected to effectively sample for juvenile size classes. Likewise, the other studies cited here used various types of sampling nets. Adult Arctic cod are excellent avoiders of such sampling equipment, and these data would be expected to underestimate the numbers of larger size classes.

Earlier evaluation of the horizontal search method indicated that we could detect a fish close enough to the ice surface so as to be touching it. Tests to determine maximum distance of target separation from the ice undersurface were inconclusive, but as mentioned above, they revealed that reflected acoustic energy may generate an interfering echo 
from the seabed. The effect of this interference is to truncate the horizontal sampling range to slightly more than the water depth within certain limits of depth and the amount of transmitted power. For the observations of this study, water depth exceeded the influence of this bottom reflection and such interference was not encountered.

There was another form of interference that was much more common. The range of horizontal searches was occasionally limited by echoes from a rough ice undersurface. Stalactites form during the spring as part of the ice-melting process (Lewis and Milne, 1977; Paige, 1970). For example, Green and Steele (1975) observed stalactites as long as $3 \mathrm{~m}$ in Resolute Bay during the month of June. These features have caused problems for us elsewhere in the Eastern Arctic, and the pattern of echoes we occasionally observed during the work reported here was consistent with stalactite interference.

Some have suggested that stalactites and other rough features may form protective habitat for Arctic cod and are therefore preferred habitat for this species (Bradstreet et al., 1986; Lonne and Gulliksen, 1989). We have no evidence from our work in Admiralty Inlet and elsewhere to suggest that Arctic cod prefer this habitat over the smooth under-ice surface. Indeed, our findings to date suggest that Arctic cod are quite common in areas with little under-ice surface relief.

\section{ACKNOWLEDGEMENTS}

This research was funded in part by the Northern Oil and Gas Action Program (NOGAP) through the Department of Fisheries and Oceans Canada, Central and Arctic Region. Logistic support was provided by the Polar Continental Shelf Project (PCSP), Department of Energy, Mines and Resources Canada. Members of the Ikajutit Hunters and Trappers Association of Arctic Bay provided valuable assitance in the field. $H$. Welch, S. Cosens, L. Johnson, M. Dunbar, O. Lonne and H. Hop provided constructive reviews of an earlier version of this paper.

\section{REFERENCES}

ANDRIASHEV, A.P. 1964. Fishes of the northern seas of the U.S.S.R Jerusalem: Israel Program for Scientific Translations.

1970. Cryopelagic fishes of the Arctic and Antarctic and their significance in polar ecosystems. In: Holdgate, M.W., ed. Antarctic Ecology, Vol. 1. New York: Academic Press. 297-304.

BAIN, H., and SEKERAK, A.D. 1978. Aspects of the biology of Arctic cod, Boreogadus saida, in the central Canadian Arctic. Unpubl. report by LGL Ltd. for the Polar Gas Project. Available at the Arctic Institute Library, University of Calgary, Calgary, Alberta, Canada T2N 1N4.

BAIN, H., THOMPSON, D., FOY, M., and GRIFFITHS, W. 1977. Marine ecology of fast-ice edges in Wellington Channel and Resolute Passage, N.W.T. Unpubl. report by LGL Ltd. for Polar Gas Project. Available at the Arctic Institute Library, University of Calgary, Calgary, Alberta, Canada T2N $1 \mathrm{~N} 4$.

BRADSTREET, M.S.W. 1977. Feeding ecology of seabirds along fast-ice edges in Wellington Channel and Resolute Passage, N.W.T. Unpubl. report by LGL Ltd. for Polar Gas Project. Available at the Arctic Institute Library, University of Calgary, Calgary, Alberta, Canada T2N 1 N4.

1980. Thick-billed murres and black guillemots in the Barrow Strait area, N.W.T., during spring: diets and food availability along ice edges. Canadian Journal of Zoology 58:2120-2140.

1982. Occurrence, habitat use, and behaviour of seabirds, marine mammals, and arctic cod at the Pond Inlet ice edge. Arctic 35(1):28-40. and CROSS, W.E. 1982. Trophic relationships at High Arctic ice edges. Arctic 35(1):1-12.

BRADSTREET, M.S.W., FINLEY, K.J., SEKERAK, A.D., GRIFFITHS, W.B., EVANS, C.R., FABIJAN, M.F., and STALLARD, H.E. 1986
Aspects of the biology of Arctic cod (Boreogadus saida) and its importance in arctic marine food chains. Canadian Technical Report of Fisheries and Aquatic Sciences No. 1491.

BROWN, R.G.B., and NETTLESHIP, D.N. 1981. The biological significance of polynyas to arctic colonial seabirds. In: Sterling, I., and Cleator, H., eds. Polynyas in the Canadian Arctic. Canadian Wildlife Service Occasional Paper No. 45. 59-65.

BUCKLEY, J.R., GAMMELSROD, T., JOHANNESSEN, J.A., JOHANNESSEN, O.M., and ROED, L.P. 1979. Upwelling: Oceanic structure at the edge of the arctic ice pack in winter. Science 203:165-167.

DUNBAR, M.J. 1981. Physical causes and biological significance of polynyas and other open water in sea ice. In: Sterling, I., and Cleator, H., eds. Polynyas in the Canadian Arctic. Canadian Wildlife Service Occasional Paper No. 45:29-43.

EHRENBERG, J.E. 1974. Two applications for a dual-beam transducer in hydroacoustic fish assessment systems. IEEE'74, International Conference, Engineering in the Ocean Environment 1:152-155.

FINLEY, K.J., and GIBB, E.J. 1982. Summer diet of the narwhal (Monodon monoceros) in Pond Inlet, northern Baffin Island. Canadian Journal of Zoology 60:3353-3363.

FROST, K.J., and LOWRY, L.F. 1984. Trophic relationships of vertebrate consumers in the Alaskan Beaufort Sea. In: Barnes, P.W., Schell, D.M., and Reimnitz, E., eds. The Alaskan Beaufort Sea: Ecosystems and Environments. Orlando: Academic Press. 381-401.

GASTON, A.J., and NETTLESHIP, D.N. 1981. The Thick-billed Murres of Prince Leopold Island. Canadian Wildlife Service Monograph Series No. 6.

GREEN, J.M., and STEELE, D.H. 1975. Observations on marine life beneath sea ice, Resolute Bay, N.W.T. In: Proceedings of the Circumpolar Conference on Northern Ecology, September 15-18, 1975, Ottawa. Ottawa: National Research Council. II-79 - II-86.

HANSEN, W.J., and DUNBAR, M.J. 1970. Biological causes of scattering layers in the Arctic Ocean. In: Farquhar, G.B., ed. Proceedings of an International Symposium on Biological Sound Scattering in the Ocean, March 31-April 2, 1970, Warrenton, Virginia. MC Report 005. Washington, D.C.: Maury Center for Ocean Science, Department of the Navy. 508-526.

HUNTER, J.G. 1979. Abundance and distribution of Arctic cod, Boreogadus saida, in the southeastern Beaufort Sea. CAFSAC Research Document No. 79/39. Department of Fisheries and Oceans Canada, Canadian Atlantic Fisheries Scientific Advisory Committee. Available at the Arctic Institute Library, University of Calgary, Calgary, Alberta, Canada T2N $1 \mathrm{~N} 4$.

KINGSLEY, M.C.S., STIRLING, I., and CALVERT, W. 1985. The distribution and abundance of seals in the Canadian High Arctic, 1980-82. Canadian Journal of Fisheries and Aquatic Sciences 42:1189-1210.

LEWIS, E.L., and MILNE, A.R. 1977. Underwater sea ice formations. In: Dunbar, M.J., ed. Polar Oceans, Proceedings of the Polar Oceans Conference, McGill University, Montreal, May 1974. Montreal: Arctic Institute of North America. 239-245.

LONNE, O.J., and GULLIKSEN, B. 1989. Size, age and diet of polar cod, Boreogadus saida (Lepechin 1773), in ice covered waters. Polar Biology 9(3):187-191.

LOWRY, L.F., and FROST, K.J. 1981. Distribution, growth, and foods of Arctic cod (Boreogadus saida) in the Bering, Chukchi, and Beaufort seas. Canadian Field-Naturalist 95(2):186-191.

MANSFIELD, A.W. 1983. The effects of vessel traffic in the Arctic on marine mammals and recommendations for future research. Canadian Technical Report of Fisheries and Aquatic Sciences No. 1186.

, SMITH, T.G., and BECK, B. 1975. The narwhal (Monodon monoceros) in eastern Canadian waters. Journal of the Fisheries Research Board of Canada 32:1041-1046.

MOORE, J.W., and MOORE, I.A. 1974. Food and growth of Arctic char, Salvelinus alpinus (L.) in the Cumberland Sound area of Baffin Island. Journal of Fish Biology 6(1):79-92.

PAIGE, R.A. 1970. Stalactite growth beneath sea ice. Science 167:171-172.

QUAST, J.C. 1974. Density distribution of juvenile Arctic cod, Boreogadus saida, in the eastern Chukchi Sea in the fall of 1970. Fishery Bulletin 72:1094-1105.

SCOTT, W.B., and SCOTT, M.G. 1988. Atlantic Fishes of Canada. Canadian Bulletin of Fisheries and Aquatic Sciences No. 219.

SEKERAK, A.D., and RICHARDSON, W.J. 1978. Studies of the ecology of the fast-ice edges in the High Arctic. Unpubl. report by LGL Ltd. Available at the Arctic Institute Library, University of Calgary, Calgary, Alberta, Canada T2N 1N4.

SERGEANT, D.E. 1973. Feeding, growth and productivity of northwest Atlantic harp seals (Pagophilus groenlandicus). Journal of the Fisheries Research Board of Canada 30:17-29. 